quaternary ganglionic blocking agent chlorisondamine, which dose not cross the blood-brain barrier, have shown that the increased norepinephrine turnover in the heart of the hypertensive animals can be normalized, whereas the delayed turnover in medulla oblongata and hypothalamus persists.

\title{
REFERENCES
}

1) de Champlain, J., Krakoff, L.R., Mueller, R.A. and Axelrod, J.: Biochim. Appl. 14, Suppl. 1, 119 (1968); 2) Lours, W.J., Spector, S., Tabet, R. and SJoerdsma, A.: Circulation Res. 24, 85 (1969); 3) Thoznen, H.: Bildung und funktionelle Bedeutung adrenerger Ersatz-transmitter. In: Experimentelle Medizin, Pathologie und Klinik, Band 27, Springer, Berlin (1969); 4) de Champlain, J., Muelder, R.A. and Axelrod, J.: Circulation Res. 25, 285 (1969); 5) de Champlain, J., Krakoff, L.R. And Axelrod, J.: Circulation Res. 23, 479 (1968); 6) Abrams, M. and Sobin, S.: Proc. Soc. exp. Biol. Med. 64, 412 (1967); 7) Gerold, M. And Tschirky, H.: Arzneimittel Forsch. 18, 1285 (1968); 8) Spector, S., SJoerdsma, A. and Udenfriend, S.: J. Pharmac. exp. Ther. 147, 86 (1965); 9) Friedman, A.H. And Walker, C.A.: J. Physiol. 197, 77 (1968); 10) Glowinski, J. And Iversen, L.: J. Neurochem. 13, 655 (1966); 11) von Euler, U.S. and Lishajko, F.: Acta physiol. scand. 51, 348 (1961); 12) Anton, A.H. and Sayre, D.F.: J. Pharmac. exp. Ther. 138, 360 (1962)

\section{EFFECTS OF p-GHLOROPHENYLALANINE, A SEROTONIN DEPLETOR, ON SIDMAN AVOIDANGE RESPONSE IN RATS}

\author{
SHUJI TAKAORI AND CHIKAKO TANAKA \\ Department of Pharmacology, Faculty of Medicine, Kyolo University, Sakyo-ku, Kyoto
}

Received for publication August 24, 1970

Koe and Weissman (1) have demonstrated that p-chlorophenylalanine (p-CPA)* is a potent and selective depletor of brain serotonin in experimental animals. Administration of p-CPA strongly inhibits both tryptophan and phenylalanine hydroxylase activities. Several investigators have presented the studies regarding the behavioral effects of $\mathrm{p}$-CPA. The drug was found to decrease spontaneous motor activity of rats (2-4) and to reduce aggressive behavior of mice (5). On the other hand, administration of p-CPA induced sexual excitation in rats (6) and cats (7) and caused an increased rate of acquisition of the conditioned avoidance response in rats $(2,4)$. The present experiment was designed to study the effects of pC.PA on Sidman-type avoidance response in rats.

Male rats of Wistar strain, weighing about $230 \mathrm{~g}$ ( 3 months old), served as the subjects. They were housed in an individual cage. The daily-intake of a commercial diet (CLEA CA-1) was restricted to 15 g/animal allowing free access to drinking water. Sidman-type avoidance apparatus (Kyoto Keisoku Co.) was used. The rat was placed in a box for 30 minutes every day, and frequencies of lever-presses and electroshock performances were recorded. The avoidance response-shock interval was 40 seconds, the shockshock interval was 10 seconds, and the shock duration was 1 second. The rats which had received the training trials more than 20 sessions were maintained on the diet containing $0.1 \% \mathrm{p}$-GPA for 12 days. In another series of experiment, single doses of $100 \mathrm{and} 300 \mathrm{mg} / \mathrm{kg}$ of $\mathrm{p}$-CPA were administered orally in the

高折 修二・田中 千賀子

* p-CPA was kindly supplied by Carles Pfeizer and Co. Groton, Conn., U.S.A. 
rats which had recieved the training trials. A more detailed description of the experimental procedures may be found in the previous paper (8). The statistical significance of the data was determined by Student's $t$-test.

The body weight of rats was gradually reduced during the addition of p-CPA to the dict, and the mean body weight was decreased by $31.1 \mathrm{~g}(\mathrm{n}=10)$ after 12 days of this diet. No obvious alteration in the gross behavior was observed, apart from increased irritability on handling. As shown in Table 1-A, a

TABle 1. Effects of p-CPA on Sidman avoidance response. A) Addition of $0.1 \%$ p-GPA to the diet for 12 days $(n=10)$

\begin{tabular}{lcc}
\hline & $\begin{array}{c}\text { Avoidance response } \\
\text { (\% change) }\end{array}$ & $\begin{array}{c}\text { Shock } \\
\text { (\% change) }\end{array}$ \\
\hline Before & $100 \%$ & $100 \%$ \\
1st day & $111.4 \pm 10.5$ & $94.8 \pm 13.2$ \\
2nd " & $150.7 \pm 27.0$ & $77.9 \pm 11.7$ \\
3 rd " & $136.9 \pm 11.0^{* *}$ & $88.0 \pm 6.6$ \\
4 th " & $166.4 \pm 20.3^{* *}$ & $70.9 \pm 10.9^{*}$ \\
5th " & $143.8 \pm 17.9^{*}$ & $98.1 \pm 10.0$ \\
7th " & $143.7 \pm 18.2^{*}$ & $90.8 \pm 15.8$ \\
10th " & $147.6 \pm 11.6^{* *}$ & $\mathbf{8 1 . 6 \pm 6 . 8 ^ { * }}$ \\
11th "(5-HTP, 50 mg/kg i.p.) & $78.5 \pm 10.7$ & $119.6 \pm 14.6$ \\
12th " & $132.8 \pm 14.7 *$ & $86.4 \pm 12.2$ \\
\hline
\end{tabular}

After discontinuation of the p-CPA diet

\begin{tabular}{rrr}
5 th " & $124.1 \pm 21.1$ & $108.6 \pm 14.6$ \\
10 th " & $92.2 \pm 7.3$ & $105.2 \pm 9.1$ \\
\hline
\end{tabular}

B) Single oral administration of p-CPA $(n=8)$

\begin{tabular}{|c|c|c|c|c|}
\hline $\begin{array}{c}\mathrm{p}-\mathrm{CPA}(\mathrm{mg} / \mathrm{kg}) \\
(24 \mathrm{hr} \text { before the } 1 \text { st } \\
\text { day-testing) }\end{array}$ & & 100 & 300 & $\begin{array}{c}300+5-\mathrm{HTP}(50 \mathrm{mg} / \mathrm{kg} \\
\text { i.p., I hr before the } \\
\text { 1st day-testing) }\end{array}$ \\
\hline \multirow{8}{*}{$\begin{array}{l}\text { Avoidance response } \\
(\% \text { change })\end{array}$} & Before & $100 \%$ & $100 \%$ & $100 \%$ \\
\hline & 1st day & $142.5 \pm 24.5$ & $172.9 \pm 14.1^{* *}$ & $118.4 \pm 10.5$ \\
\hline & 2nd " & - & $195.7 \pm 27.6 * *$ & $178.3 \pm 28.8^{* * *}$ \\
\hline & $3 \mathrm{rd} "$ & $173.2 \pm 32.6^{*}$ & $189.9 \pm 21.1^{* * k}$ & $176.7 \pm 24.0^{* *}$ \\
\hline & 4 th " & $114.8 \pm 14.2$ & $223.2 \pm 36.5^{* *}$ & $175.2 \pm 24.1^{* *}$ \\
\hline & 5 th " & $136.0 \pm 19.1$ & $231.1 \pm 35.2 * *$ & $179.5 \pm 29.9 *$ \\
\hline & 7 th $"$ & $123.3 \pm 12.2$ & $149.7 \pm 29.5$ & $148.9 \pm 22.0^{*}$ \\
\hline & 10th " & $121.9 \pm 22.1$ & $122.9 \pm 15.1$ & $112.7 \pm 12.6$ \\
\hline \multirow{8}{*}{$\begin{array}{l}\text { Shock } \\
\text { (\% change })\end{array}$} & Before & $100 \%$ & $100 \%$ & $100 \%$ \\
\hline & 1st day & $87.0 \pm 7.2$ & $76.9 \pm 7.5^{++}$ & $106.4 \pm 4.7$ \\
\hline & 2nd " & - & $76.1 \pm 8.9^{+}$ & $73.2 \pm 12.2^{+}$ \\
\hline & $3 \mathrm{rd} "$ & $77.3 \pm 7.0^{++}$ & $65.1 \pm 9.2^{+}$ & $68.5 \pm 8.1^{++}$ \\
\hline & 4 th $"$ & $95.4 \pm 9.6$ & $87.8 \pm 10.2$ & $53.7 \pm 7.3^{+}$ \\
\hline & 5th " & $96.9 \pm 7.2$ & $71.9 \pm 7.1^{++}$ & $67.4 \pm 12.0^{+}$ \\
\hline & 7 th $"$ & $87.3 \pm 9.6$ & $92.7 \pm 13.3$ & $100.9 \pm 14.2$ \\
\hline & 10 th $"$ & $98.9 \pm 7.5$ & $96.0 \pm 17.9$ & $96.6 \pm 12.9$ \\
\hline
\end{tabular}

Mean+S.E.

Significant increase : $* * \mathrm{P}<0.01, * \mathrm{P}<0.05$.

Significant decrease : ${ }^{++} \mathrm{P}<0.01,{ }^{*} \mathrm{P}<0.05$. 
significant increase $(P=0.01$ or 0.05$)$ in the avoidance response rate with a decrease in the number of shocks was found from the 3rd day of the P-CPA diet. These changes in the avoidance responses and shocks were completely antagonized by 5-hydroxytryptophan (5-HTP; $50 \mathrm{mg} / \mathrm{kg}$ i.p.) administered 1 hour before the testing at the 11 th day. These two parameters of the avoidance behavior were restored to the control level 7 to 10 days after discontinuation of the 12-day feeding of P-CPA. As shown in Table 1-B, single administration of p-CPA also enhanced the frequency of avoidance response and decreased the number of shocks. A significant increase $(P=0.01)$ in the avoidance response rate was obtained from 1 to 5 days after $300 \mathrm{mg} / \mathrm{kg}$ of $\mathrm{p}-\mathrm{CPA}$, and it recovered to the control level at 10 days after the administration. The responses of the avoidance behavior to $\mathrm{p}$-CPA were abolished by treatment of the animals with 5HTP (50 mg/kg i.p.) 1 hour before the 1 st day-testing after p-CPA, but the time-course of changes in these two parameters later than the 2nd day was almost similar to that in the animals treated with pCPA alone. Single intraperitoneal injection of $5-H T P(50 \mathrm{mg} / \mathrm{kg})$ did not affect the number of avoidance responses and shocks.

There are three possible explanation of the present behavioral changes caused by p-CPA: 1) direct action of $\mathrm{p}$-CPA, 2) increase in phenylalanine level, and 3) serotonin depletion in the brain. After the administration of p-CPA, the level of p-CPA itself in the brain increased quickly, and then little p-CPA was present 3 days after the administration $(1,9)$. Brain phenylalanine level increased to the maximum level at the 2nd day and returned to the control in about 4 days. However, serotonin content in the brain decreased markedly for several days after the administration of p-CPA, and slowly returned to the normal level over a period of 10 days $(1,9)$. Therefore, an excellent correlation between the degree of facilitation of the Sidman avoidance performance and serotonin depletion caused by p-CPA indicates the concept that this drastic decrease in the brain serotonin is probably the critical event for facilitation of the avoidance behavior. This conclusion was also supported by the present results that an increase in the avoidance response rate induced by p-CPA was reversed by the supplement of 5-HTP. The effects of $\alpha$-methyl-p-tyrosine, an inhibitor of tyrosine hydroxylase, on the Sidman avoidance response will be reported elsewhere.

\section{REFERENCES}

1) Koe, B.K. And Weissman, A.: J. Pharmac. exp. Ther. 154, 499 (1966); 2) Tenen, S.S.: Psychopharmac. 10, 204 (1967); 3) Volicer, L.: Int. J. Neuropharmac. 8, 361 (1969); 4) Brody, J.F. JR.: Psychopharmac. 17, 14 (1970); 5) Welch, A.S. And Welch, B.L.: Biochem. Pharmac. 17, 699 (1968); 6) Tagliamonte, A., Tagliamonte, P., Gessa, G.L. And Brodie, B.B.: Science, N.Y. 166, 1433 (1969); 7) Ferguson, J., Henriksen, S., Cohen, H., Mrtchelt, G., Barchas, J. and Dement, W.: Science, N.Y. 168, 499 (1970); 8) Takaori, S., Yada, N. and Mori, G.: Jap. J. Pharmac. 19, 587 (1969); 9) JÉquier, E., Lovenberg, W. and Sjoerdsma, A.: Mol. Pharmac. 3, 274 (1967) 